\title{
Molting of megalopae from the blue crab Callinectes sapidus: effects of offshore and estuarine cues
}

\author{
Richard B. Forward Jr, David A. Z. Frankel, Dan Rittschof \\ Duke University, School of the Environment, Marine Laboratory, Beauiort, North Carolina 28516, USA
}

\begin{abstract}
Postlarvae (megalopae) of the blue crab Callinectes sapidus (Rathbun) are transported from shelf/coastal areas into estuaries where they metamorphose (molt) to the first crab stage. This study tested the hypothesis of Wolcott \& DeVries (1994; Mar. Ecol. Prog. Ser. 109: 157-163) that metamorphosis is delayed in offshore water and accelerated by cues associated with estuaries. The effects of offshore water, estuarine water, adult blue crab odors, eelgrass Zostera marina and salinity were tested by measuring the time until molting. Test megalopae were collected as they entered an estuary. Molting was slowest in offshore water, faster in estuarine water and fastest in the presence of eelgrass. Adult odors had no effect on molting, however, a decrease in salinity decreased molting time. These results support the hypothesis and indicate blue crab megalopae should preferentially undergo metamorphosis in estuarine seagrass beds.
\end{abstract}

KEY WORDS: Blue crab · Callinectes sapidus · Molting $\cdot$ Chemical cues

\section{INTRODUCTION}

Blue crabs Callinectes sapidus inhabit estuaries as adults. During the life cycle, larvae released by females near the mouths of estuaries are transported offshore and develop on the continental shelf (Williams 1984). Postlarvae (megalopae) are abundant in surface waters (Smyth 1980, McConaugha et al. 1983, Epifanio 1988, Epifanio et al. 1989) and are transported primarily by wind-generated surface currents shoreward toward estuaries (Epifanio et al. 1984, Goodrich et al. 1989). Up-estuary movement is mainly accomplished by flood-tide transport, in which megalopae are in the water column during rising tides at night and absent at other times (Dittel \& Epifanio 1982, Brookins \& Epifanio 1985, Little \& Epifanio 1991, DeVries et al. 1994).

Wolcott \& DeVries (1994) hypothesized that metamorphosis of blue crab megalopae to the first crab stage was delayed in offshore water and accelerated by cues associated with estuaries. Evidence supporting this hypothesis was that none of the megalopae from offshore surface or bottom areas were in active premolt. Furthermore, the time until metamorphosis was accelerated by $10 \%$ upon exposing offshore megalopae to low salinity water from an estuarine marsh (Wolcott \& DeVries 1994).

The present study retested this hypothesis with megalopae collected as they entered an estuary. The time until metamorphosis was used as an assay for the effect of offshore water, estuarine water, adult odors, eelgrass and salinity. An assumption was that progression toward metamorphosis was initiated during transport into the estuary. We predicted that a return to offshore water should delay metamorphosis. Since the other conditions represented indicators of an estuarine environment, we also predicted that they should accelerate metamorphosis. A salinity decrease is encountered as megalopae move farther into an estuary. Adult odors would indicate arrival at a location suitable for habitation and may accelerate metamorphosis as has been found for fiddler crabs (Christy 1989, O'Connor 1991). Finally, the abundance of megalopae and first stage crabs in seagrass beds (Heck \& Thomas 1984) suggests that metamorphosis is stimulated by estuarine vegetation (Orth \& van Montfrans 1987, Lipcius et al. 1990, Olmi et al. 1990). 


\section{MATERIALS AND METHODS}

Megalopae of the blue crab Callinectes sapidus (Rathbun) were collected in plankton tows $10.67 \mathrm{~m}$ diameter net; $500 \mu \mathrm{m}$ mesh) from September to November (1993) about $1 \mathrm{~km}$ inside the entrance of the Newport River estuary (Beaufort, North Carolina, USA), on rising tides at night. Megalopae were maintained in ambient estuarine water until the beginning of experiments the next day. No attempt was made to determine the molt stages of the megalopae, and it was assumed that the distribution of molt stages was similar in all experiments.

The general experimental procedure was to place groups of 10 megalopae in finger bowls $19 \mathrm{~cm}$ diameter) containing the test water. Megalopae were maintained in a controlled environmental chamber $\left(20^{\circ} \mathrm{C}\right.$; Sherer Model CEL4-4) on a light:dark cycle similar to ambient. Water was changed daily and megalopae were fed newly hatched brine shrimp nauplii (Artemia sp.). Glassware was scrubbed in deionized water and rinsed twice to prevent contamination between different test conditions. Megalopae that molted to first crab were removed daily and the time between collection and molting was recorded to the nearest day. The experiment continued until all megalopae had molted.

Four experiments were performed. In the first, larvae were exposed to water collected about $15 \mathrm{~km}$ offshore. This water was beyond the estuarine plume and from an area where megalopae were collected in the neuston for other experiments (Forward \& Rittschof 1994). This water was collected the day the experiment began, filtered to remove particles larger than $5 \mu \mathrm{m}$ and stored in acid-washed glass carboys at room temperature throughout the experiment. To measure the effect of salinity on molting, this water was tested at 3 salinities (ambient $=35,25$ and $18 \mathrm{ppt}$ ). These salinities were used in all experiments and were prepared by dilution with deionized well water. An unavoidable consequence was that dilution also reduced the effective concentration of any chemical cues. Salinity was measured with a refractometer (AO, accuracy = $0.5 \mathrm{ppt}$ ). Megalopae were placed directly in $25 \mathrm{ppt}$. For $18 \mathrm{ppt}$, megalopae were placed in $25 \mathrm{ppt}$ for $1 \mathrm{~h}$ before transfer to $18 \mathrm{ppt}$. Preliminary experiments indicated that increasing the acclimation time in $25 \mathrm{ppt}$ to $1 \mathrm{~d}$ did not affect time of molting.

The second experiment was identical to the first except that estuarine water was used. Estuarine water was obtained at the site of megalopal collection and had a salinity of about $35 \mathrm{ppt}$. The third experiment tested whether adults emit an odor that stimulates molting. Each day a male adult blue crab (carapace width $=15 \mathrm{~cm}$ ) was incubated in ambient estuarine water for $24 \mathrm{~h}$. This water was removed and tested at the 3 salinities. The adult crab was then incubated in new estuarine water for use the next day. The effect of the presence of eelgrass Zostera marina was tested in the fourth experiment. The procedure was identical to that with estuarine water (second experiment) except that 5 or 6 blades of newly collected eelgrass were present in each bowl. Only blades that were considered healthy due to their green color were used.

In each experiment, a cohort of megalopae was simultaneously tested at all salinities. Each experimental treatment consisted of 6 or 9 replicate bowls, each containing 10 megalopae. The mean time until molting to the first crab stage was calculated for each replicate bowl and treated as an individual variate. The procedure was used to reduce possible bowl effects. Data were then analyzed as an unbalanced 2-way ANOVA using the General Linear Models procedure in the SAS statistical analysis package (SAS Institute, Cary, NC, USA). Data were log transformed to improve homogeneity of variance and normality. Type III sums of squares (Goodnight 1978, Shaw \& Mitchell-Olds 1993) were utilized. Since the experimental design incorporated only fixed treatment effects, $F$ statistics for salinity, water type, and their interaction were calculated by dividing the appropriate mean square by the mean square error. Due to the unbalanced cell frequencies and the resulting lack of orthogonality in the analysis, the sums of squares in Table 2 are not additive (Sokal \& Rohlf 1981). Since there was no significant interaction effect of salinity and water type (see 'Results') Tukey's studentized range was used to compare among means by treating either water type or salinity factor as a block effect and defining the other factor as the variable of interest. Tukey's studentized range was carried out using SAS and employing an experimentwise error rate of 0.05 .

\section{RESULTS}

Molting time (Table 1) changed significantly with water type and salinity (Table 2). Since there was no interaction effect (Table 2), the influences of water type and salinity were considered separately. The effect of water type was evident at $35 \mathrm{ppt}$. Times were longer in offshore water (mean $=4.37 \mathrm{~d}$ at $35 \mathrm{ppt}$ ) than any other condition (Table 1). In estuarine water with and without adult odor the times were not different but both were about $1 \mathrm{~d}$ shorter than in offshore water (Estuary mean $=3.48$ d at 35 ppt; Adult odor mean $=$

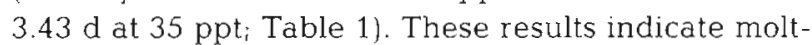
ing was not affected by the presence of adult odor. Finally, megalopae molted the fastest (Table 1) in estuarine water containing eelgrass (mean $=2.88 \mathrm{~d}$ at $35 \mathrm{ppt}$. 
Table 1. Callinectes sapidus. Mean time (d) and standard deviation until molting to the first crab stage of megalopae. Water types were offshore, estuary, estuary with adult odor and estuary with eelgrass at 3 different salinities. Sample size was 6 in all experiments except where noted as 9 . Different letters after the water type and salinity indicate that the mean time was significantly different $(p<0.05)$

\begin{tabular}{|lllllll|}
\hline \multirow{2}{*}{$\begin{array}{l}\text { Water } \\
\text { type }\end{array}$} & \multicolumn{2}{c}{$35 \mathrm{ppt}^{\mathrm{d}}$} & \multicolumn{2}{c}{$25 \mathrm{ppt}^{\text {ab }}$} & \multicolumn{2}{c|}{ 18 ppt ${ }^{\mathrm{b}}$} \\
& Mean & SD & Mean & SD & Mean & SD \\
\hline Offshore $^{\mathrm{d}}$ & $4.37(9)$ & 0.94 & $3.82(9)$ & 0.66 & 3.42 & 0.44 \\
Estuary $^{\mathrm{b}}$ & $3.48(9)$ & 0.18 & $3.38(9)$ & 0.42 & 3.38 & 0.47 \\
Adult odor $^{\mathrm{b}}$ & 3.43 & 0.26 & 3.33 & 0.18 & 3.52 & 0.23 \\
Eelgrass $^{\mathrm{c}}$ & 2.88 & 0.22 & 2.55 & 0.18 & 2.55 & 0.41 \\
\hline
\end{tabular}

Table 2. ANOVA for water type and salinity effect

\begin{tabular}{|lrccrr|}
\hline Source & df & Type III SS & MS & F-value & p > F \\
\hline Water type & 3 & 14.892 & 4.9639 & 21.98 & 0.0001 \\
Salinity & 2 & 1.6499 & 0.8249 & 3.65 & 0.0308 \\
Water type $\times$ Salinity & 6 & 2.1512 & 0.3585 & 1.59 & 0.1631 \\
Error & 72 & 16.257 & 0.2258 & & \\
\hline
\end{tabular}

Lowering the salinity generally decreased molting time. Treating water type as a block effect, molting rates at salinities of $35 \mathrm{ppt}$ versus $25 \mathrm{ppt}$ and 25 versus 18 ppt were not significantly different (Table 1); molting rates in $18 \mathrm{ppt}$, however, were significantly shorter than in $35 \mathrm{ppt}$.

\section{DISCUSSION}

Blue crab larvae molt to the megalopal stage in continental shelf areas are transported shoreward (Epifanio et al. 1984, Goodrich et al. 1989), and once within the vicinity of an estuary achieve movement up the estuary by flood tide transport (Dittel \& Epifanio 1982, Brookins \& Epifanio 1985, Little \& Epifanio 1991, DeVries et al. 1994). Megalopae molt to first crab in benthic habitats suitable for survival and future growth (van Montfrans et al. 1990, Wilson et al. 1990).

The average molt stage of megalopae progresses from postmolt to intermolt and then premolt as they move from the shelf to estuarine areas (Metcalf \& Lipcius 1992). Nevertheless, since megalopae do not enter the estuary in late premolt, they retain time for some degree of habitat selection (Lipcius et al. 1990). The present study suggests that this time window is about $5 \mathrm{~d}$, as the longest mean time to molting for megalopae collected near the mouth of the estuary was close to $5 \mathrm{~d}$ (Table 1). There are 2 possible explanations for the inability to substantially delay molting. First, the estuarine cues detected prior to and during collection could have begun the sequence toward metamorphosis. Second, laboratory maintenance conditions irreversibly began the molting sequence. The second alternative was suggested by Wolcott \& DeVries (1994), who found that megalopae collected offshore in both the neuston and bottom were in intermolt. Nevertheless, once held in laboratory conditions, they proceeded to metamorphosis with a mean time until molting of about 5 to $6 \mathrm{~d}$. Thus, actual molting times under natural conditions may be longer than observed in the experiments.

The present study clearly indicates that water conditions can delay or accelerate molting within this $5 \mathrm{~d}$ time window. If megalopae were maintained in estuarine water from the collection site, the mean time until metamorphosis was $3.48 \mathrm{~d}$ (35 ppt; Table 1). When megalopae were returned to offshore water (35 ppt), metamorphosis slowed, as the mean time until molting was $4.37 \mathrm{~d}$ (Table 1). This time was not significantly different (Student's t-test) from that found by Wolcott \& DeVries (1994) for megalopae collected offshore and held in $32 \mathrm{ppt}$ offshore water (mean $=4.93 \mathrm{~d} ; \mathrm{SD}=1.08 ; \mathrm{n}=22$ ). Thus, if megalopae are transported from estuarine areas back offshore, molting will be delayed which increases the time for possible movement back to the estuary. Costlow (1967) and Sulkin \& van Heukelen (1986) reach a similar conclusion by demonstrating that the megalopae stage was prolonged by exposure to high salinity water representative of offshore water.

In the present study, molting time decreased as salinity decreased in contrast to the results of Wolcott \& DeVries (1994) with megalopae collected offshore. A possible explanation is that their lowest salinity (26 ppt) was not low enough to affect molting. However, our results agree with those of Costlow \& Bookhout (1959), who found that when larvae were released and reared in the laboratory, the duration of the entire megalopal stage shortened with decreasing salinity (20.1 ppt = lowest test salinity). Thus, estuarine chemical cues and lower salinity accelerate molting, but the effects are not additive. For example, the mean times in $18 \mathrm{ppt}$ in estuarine and offshore water were not significantly different (Student's $t$-test; Table 1).

Adult fiddler crabs (O'Connor 1994) and barnacles (Rittschof 1985) produce water-soluble pheromones that induce settlement and metamorphosis of larvae. There was no such effect for blue crabs, since molting times did not change in the presence of water previously occupied by an adult. This result is perhaps 
expected, since blue crabs differ from both fiddler crabs and barnacles in that they live throughout an estuary, and there is no specific location for adults. Thus, adult odor may not affect molting or it may be at sufficient levels in the natural estuarine water used in the experiments such that additional odor has no additional effect.

Distribution studies indicate beds of submerged vegetation are important nursery areas for blue crabs (Heck \& Orth 1980, Heck \& Thoman 1984), and megalopae preferentially settle in seagrass beds (Orth $\&$ van Montfrans 1987, Olmi et al. 1990). The present study supports these observations, since the presence of eelgrass accelerated metamorphosis. The mean time to molt was $2 \mathrm{~d}$ shorter than in offshore water and $1 \mathrm{~d}$ shorter than in estuarine water alone. Since megalopae were observed to cling to the eelgrass, the blades were probably providing both chemical and structural cues. Future studies are needed to differentiate between these cues. Thus, if megalopae encounter eelgrasses, they will cling to them and accelerate metamorphosis.

This study provides further support for the hypothesis that metamorphosis of blue crab megalopae is delayed in offshore areas and accelerated by estuarine cues (Wolcott \& DeVries 1994). Molting was slowest in offshore water, faster in estuarine water and fastest in estuarine water containing eelgrass. These results clearly indicate the importance of seagrasses as nursery areas for blue crabs.

Acknowledgements. This material is based on research supported by the National Science Foundation (OCE-9114960). We thank Drs M. DeVries, D. Gerhart and D. Wolcott for critically reading the manuscript and Drs D. Gerhart and E. Holm for assistance with the statistics.

\section{LITERATURE CITED}

Brookins, K. G., Epifanio, C. E. (1985). Abundance of brachyuran larvae in a small coastal inlet over 6 consecutive tidal cycles. Estuaries 8: 60-67

Christy, J. H. (1989). Rapid development of megalopae of the fiddler crab Uca pugilator reared over sediment: Implications for models of larval recruitment. Mar. Ecol. Prog. Ser. 57: $259-265$

Costlow, J. D. Jr (1967). The effect of salinity and temperature on survival and metamorphosis of megalopae of the blue crab Callinectes sapidus. Helgoländer wiss. Meeresunters. 15: $84-97$

Costlow, J. D. Jr, Bookhout, C. G. (1959). The larval development of Callinectes sapidus Rathbun reared in the laboratory. Biol. Bull. 116: 373-396

De Vries, M. C., Tankersley, T A., Forward, R. B. J., KirbySmith, W. W., Luettich, R. A. (1994). Abundances of crab megalopae are associated with estuarine tıdal hydrologic variables. Mar. Biol. 118: 403-413

Dittel, A. I., Epifanio, C. E. (1982). Seasonal abundance and vertical distribution of crab larvae in Delaware Bay, USA Estuaries 5: 197-202

Epifanio, C. E. (1988). Transport of invertebrate larvae between estuaries and the continental shelf. Am. Fish. Soc. Symp. 3: 104-114

Epifanio, C. E., Masse, A. K., Gravine, R. W. (1989). Transport of blue crab larvae by surface currents off Delaware Bay USA. Mar. Ecol. Prog. Ser. 54: 35-41

Epifanio, C. E., Valenti, C. C., Pembroke, A. E. (1984). Dispersal and recruitment of blue crab larvae in the Delaware Bay, USA. Estuar. coast. Shelf Sci. 18: 1-12

Forward, R. B. Jr, Rittschof, D. (1994). Photoresponses of crab larvae in offshore and estuarine waters: implications for transport. J. exp. mar. Biol. Ecol. (in press)

Goodnight, J. H. (1978), Tests of hypotheses in fixed effects linear models. SAS Technical Report R-101. SAS Institute, Cary, NC

Goodrich, D. M., van Montfrans, J., Orth, R. J. (1989). Blue crab megalopal influx to the Chesapeake Bay: evidence for a wind-driven mechanism. Estuar. coast. Shelf Sci. 29: $247-260$

Heck, K. L. Jr, Orth, R. J (1980). Seagrass habitats: the roles of habitat complexity, competition and predation in structuring associated fish and motile macroinvertebrate assemblages. In: Kennedy, V. S. (ed.) Estuarine perspectives. Academic Press, New York, p. 449-464

Heck, K. L. Jr, Thomas, T A. (1984). The nursery role of seagrass meadows in the upper and lower reaches of the Chesapeake Bay. Estuaries 7: 70-92

Lipcius, R. N., Olmi, E. J. III, van Montfrans, J. (1990). Planktonic availability, molt stage and settlement of blue crab postlarvae. Mar. Ecol. Prog. Ser. 58: 235-242

Little, K. T., Epifanio, C. E. (1991). Mechanism for the reinvasion of the estuary by two species of brachyuran megalopae. Mar. Ecol. Prog. Ser. 68: 235-242

McConaugha, J. R., Johnson, D. F., Provenzano, A. J., Maris, R. C. (1983). Seasonal distribution of larvae of Callinectes sapidus (Crustacea: Decapoda) in the waters adjacent to Chesapeake Bay. J. crust. Biol. 3: 582-591

Metcalf, K. S., Lipcius, R. N. (1992). Relationship of habitat and spatial scale with physiological state and settlement of blue crab postlarvae in Chesapeake Bay. Mar. Ecol. Prog. Ser. 82: 1.43-150

O'Connor, N. J. (1991). Flexibility in timing of the metamorphic molt by fiddler crab megalopae Uca pugilator. Mar. Ecol. Prog. Ser. 68: 243-247

Olmi, E. J. III, van Montfrans, J., Lipcius, R. N., Orth, R. J., Sadler, P. W. (1990). Variation in planktonic availability and settlement of blue crab megalopae in the York River, Virginia. Bull. mar. Sci. 46: 230-243

Orth, R. J., van Montfrans, J. (1987). Utilization of a seagrass meadow and tidal marsh creek by blue crabs Callinectes sapıdus. L. Seasonal and annual variations in abundance with emphasis on post-settlement juveniles. Mar. Ecol. Prog. Ser. 41: 283-294

Rittschof, D. (1985). Oyster drills and the frontiers of chemical ecology: unsettling ideas. Am. malacol. Bull. (Spec. Edn) 1: $111-116$

Shaw, R. G., Mitchell-Olds, T (1993). ANOVA for unbalanced data: an overview. Ecology 74: 1638-1645

Smyth, P. O. (1980). Callnectes (Decapoda: Portunidae) larvae in the Middle Atlantic Bight, 1975-1977. Fish. Bull. U.S. 78: 251-265

Sokal, R. R., Rohlf, F. J. (1981). Biometry, 2nd edn. W. H. Freeman and Co., New York

Sulkin, S. D., van Heukelen, W. F. (1986). Vanability in the length of the megalopae stage and its consequences to 
dispersal and recruitment in the portunid crab Callinectes sapidus Rathbun. Bull. mar. Sci. 39: 269-278

van Montfrans, J., Peery, C. A., Orth, R. J. (1990). Daily, monthly and annual settlement patterns by Callinectes sapidus and Neopanope sayi megalopae on artificial collectors deployed in the York River, Virginia: 1985-1988. Bull. mar. Sci. 46: 214-229

Williams, A. B. (1984). Shrimps, lobsters, and crabs of the Atlantic coast of the Eastern United States, Maine to

This article was submitted to the editor
Florida. Smithsonian Inst. Press, Washington, DC

Wilson, K., Able, K., Heck, K. Jr (1990). Predation rates on juvenile blue crabs in estuarine nursery habitats: evidence for the importance of macroalgae (Ulva lactuca). Mar. Ecol. Prog. Ser. 58: 243-251

Wolcott, D. L., De Vries, M. C. (1994). Offshore megalopae of Callinectes sapidus: depth of collection, molt stage and response to estuarine cues. Mar. Ecol. Prog. Ser. 109: $157-163$

Manuscript first received: March 1, 1994

Revised version accepted: July 13, 1994 